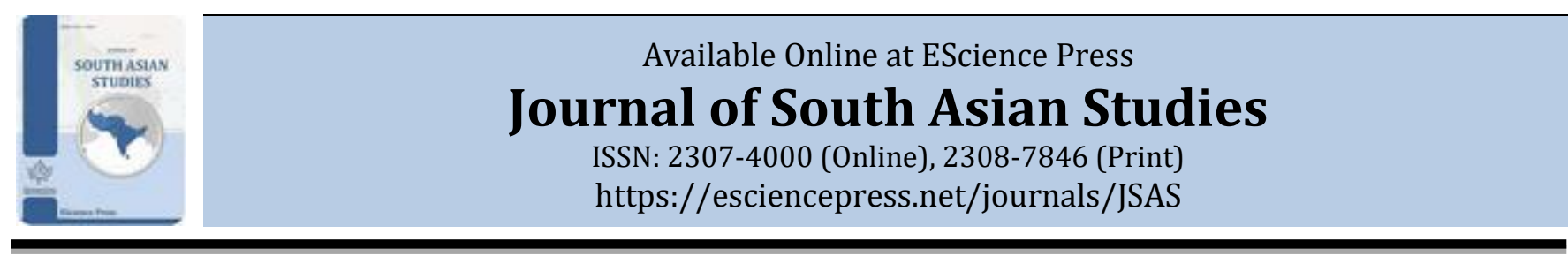

\title{
Franco-Indian Maritime Cooperation: Implications for the Indo-Pacific
}

\author{
Alik Naha, \\ State-Aided College Teachers (SACT -I), Department of Political Science, Vidyasagar College, Kolkat, West Bengal, India. \\ *Corresponding Author Email ID: aliknaha@gmail.com
}

\section{A B S T R A C T}

With the shift of the global power center from Europe to Asia, the Indo-Pacific, regarded as the "maritime underbelly" has become the center of geo-economics and geostrategic contestation. This significance of the Indo-Pacific maritime realm has drawn the attention of several regional and extra-regional powers since the past decade. In this changing geopolitical scenario, maritime security has acquired primacy in Indian foreign policy discourse. To counter the growing Chinese presence in its strategic backyard, New Delhi is increasingly looking for partners to advance the idea of 'Free, Open, and Inclusive Indo-Pacific' and also to establish itself as a net security provider in the Indian Ocean Region. France is also skeptical of assertive China as a threat to its regional interests. Since 1998, France is India's allweather strategic partner. With their shared Indo-Pacific strategy, there is a greater opportunity for them to cooperate in the Indo-Pacific region. Coupled with this bilateral opportunity, the idea of trilateral or minilateral is also gaining ground. Whatever may be the motivation, if realized such frameworks can have far-reaching ramifications. In this context, the paper seeks to analyze the implications of the Franco-Indian relationship in the Indo-Pacific region.

Keywords: India, France, Indo-Pacific, Trilateral, and Maritime Security.

\section{INTRODUCTION}

"The sculpted faces on Hindu temples, the smiling bodhisattvas, and the dreaming Angel of the Reims Cathedral" - André Malraux (Rault, 2013).

This cultural affinity formed the root of the strategic partnership between India and France, realized in 1998. Describing it as a "partnership for the $21^{\text {st }}$ century", President Chirac observed, "I came with the proposition to build a strong relation between our two countries, a global partnership grounded on our complementarities and our common interests" (Rault, 2013). These interests included cooperation in areas of space, nuclear energy, defense, and terrorism. In 2013, reminding the centrality of India in France's Asia policy, French Minister of Defense Jean-Yves Le Drian regarded India as a "major priority" while complementing the developments in Indo-French strategic partnership. This closeness in India-France relations, overcoming the fluctuations, gained ground with the end of the Cold War. The renewed French approach towards India with the dawn of the new century gained momentum following the publication of the
Defense White Paper in 2008. The White Paper mentioned, "Looking to 2025, Asia will be one of the major centers of international life, alongside Europe and America. New powers will have emerged; China and India were foremost among them" (The French White Paper on Defence and National Security, 2008).

A key element that has strengthened the India-France strategic partnership is the shared view of multipolar world order. Post-Independence, India's propagation of the non-aligned view made it clear to the western powers that New Delhi was a copy of the western idea of Democracy. It practiced economic protectionism even when democracies around the world championed a freemarket economy. Even in the post-Cold War era, for a long time, India held this non-aligned view as one of the principal determinants of its foreign policy discourse. To pursue its national interests, India engaged with every major power like the US, European Union, China, Japan, Canada, etc. These engagements were mostly issue specific. To reform the UNSC, it forged an alliance or 'G4' with countries like Germany, Brazil, and Japan. France has 
been a strong advocate of the Indian permanent seat at the UNSC. Paris also invited India as a 'special invitee' to attend the G7 summit held in 2019 (Shukla, 2019). It wants greater participation of India in the decisionmaking process of the G7. Also, on the issue of nuclear multipolarity, France and India share the same view. After India tested its nuclear weapons first in 1974 and again in 1998, France, apart from Russia, stood in support of India while condemning global sanctions. France was also instrumental in supporting India to obtain a special waiver in the Nuclear Suppliers Group in 2008. It was a landmark event that allowed India to engage in civil nuclear trade (Gireesh, 2020).

In the words of Le Drian, India is a stability factor for France in the broader Asian security framework. Apart from the close defense ties, India and France are actively cooperating in the Indian Ocean maritime domain. India considers the Indian Ocean as its strategic backyard. France also views itself as a 'Resident Power' in the Indian Ocean Region due to the presence of its Overseas territories. These overseas territories constitute the largest EEZ in the world. Therefore, by partnering with India, France wants to retain its security and economic interests in the region. Together, India and France are members of the Indian Ocean Symposium and the Indian Ocean Rim Association. These multilateral arrangements allow them to engage with the littoral states of the Indian Ocean. French military bases at Djibouti and UAE allow it to keep surveillance in the Western Indian Ocean. France and India, coupled with their close ties with the East African nations, are engaged in joint patrolling operations in the Western Indian Ocean Region. The signing of the Mutual Logistics Support Agreement (MLSA) in 2019 between India and France has provided the Indian Navy greater scope and operational ability in the region. It will help India to utilize the French bases and also to establish itself as a net security provider in the region. The joint naval exercise "Varuna" between India and France is a major step towards boosting interoperability and promoting maritime coordination between the two Navies.

Also, in the Indo-Pacific, France, and India are critical of the growing Chinese hegemony. Reaffirming the role of India as a stability factor against aggressive China, French President Hollandeopined, "India reassures where China is scaring"(Rault, 2013). To address the challenge posed by rising China, both India and France are searching for partners to promote the vision of "Free, Open, and
Inclusive Indo-Pacific". In 2018, French President Macron called for a "Paris-Delhi-Canberra Axis" to uphold regional peace and balance of power. In the paper, I have also tried to elaborate upon the possibility of an India-France-Japan trilateral, recognizing each other limitations in the maritime domain. This collaboration can also be extended to the realm of HADR and SAR. India is a recognized "first responder" to disaster management in the Indian Ocean Region, the latest being its humanitarian assistance response to the cyclone-affected Madagascar in 2020. The consolidated maritime partnership in the Western Indian Ocean between India and France paves the path for an extended partnership in the Eastern Indo-Pacific Region (Mohan \& Baruah, 2018). Therefore, in the post-COVID19 world order, the maritime partnership between India and France should not be just limited to balancing the rise of China but aim towards achieving climate goals, sustainable development, upholding multilateralism, and digital sovereignty.

Given this background, the paper attempted to work upon the following research questions-

1. Can the Franco-Indian maritime cooperation in the Western India Ocean region be reciprocated in the Eastern sector?

2. Is there any convergence in the India-France vision of the Indo-Pacific?

3. How much can the proposed trilateral frameworks contribute to realizing the vision of "Free and Open Indo-Pacific"?

\section{METHODOLOGY \& DATA}

To write this article content analysis and observation methods have been employed. In this study, data have been collected primarily from secondary sources like different published books, journals, internet sources, published research papers and articles, newspapers, etc.

\section{CONVERGENCE OF INDO-FRENCH MARITIME INTERESTS}

The Indo-Pacific is a geopolitically and geo-economically contested space, marked by an ambiguous security environment. Here, no country is in a position to exert absolute dominance to fulfill its strategic aspirations. The situation demands enhanced bilateral partnership to secure long-standing goals. Initially, Indian establishments did not regard France as a possible maritime partner in the Indo-Pacific. They were critical of the French position as a prominent maritime power in the 
region. But with the changing regional power equilibrium, there has been a shift in India's strategic thinking. The Indian policymakers are now realizing the merits of partnering with France in the region. The presence of overseas territories - Réunion and Mayotte in the Indian Ocean and NewCaledonia and French Polynesia in the South Pacific has made France a significant force in the Indo-Pacific region. These French overseas territories constitute the largest Exclusive Economic Zone (EEZ) in the world, spanning from the Indian Ocean (24\%) to the Pacific Ocean (62\%) (Ministry of Defense, 2016). A substantial number of French citizens and armed personnel resides in the region. Paris has a military base in Djibouti and has close political and economic ties with the littoral states of the Indo-Pacific region.

Post-Cold War, India made significant changes in its foreign policy doctrine. During the days of the Cold War, India was a leading advocate of the non-alignment principle and 'military isolationism' from the two Superpowers. But with the disintegration of the Soviet Union and domestic economic reforms, India began to gradually revive its defense relations with major powers of the world (Mohan C. R., 2012). This re-engagement began in the maritime domain initially with the US and the neighboring Southeast Asian nations. Referring to India's foreign policy reorientation, former Prime Minister Vajpayee opined that India's strategic interests in the Indian Ocean extended from the Gulf of Aden to the Strait of Malacca. Concomitantly, French involvement in the Indian Ocean Region was limited to its commitments in the Middle East and Africa. It was in 2008, that the French Prime Minister realizing the changing geopolitical discourse of the Indo-Pacific, emphasized French renewed interests in the region. He argued in 2009, France "has a presence in every ocean and every latitude and is responsible for extensive marine areas under its jurisdiction. France has decided to return to its historic maritime role." (Government of the French Republic, 2009).

In its 2013 defense White paper, France considered the rise of hegemonic China as pernicious to the balance of power in the region (Government of the French Republic, 2013). This has compelled the neighbors of China to revise their maritime policy and upgrade their maritime defense capabilities. For France, this provided an opportunity to get involved in regional politics and emerge as a major defense equipment supplier. The 2013 defense White Paper mentioned, "France plays a particular role [in the Indian Ocean] reinforced by the development of privileged relations with India." (Government of the French Republic, 2013).

In the initial years, defense collaboration between India and its Western allies failed to gather momentum due to the compulsions of domestic coalition politics. The left parties and many within the ruling UPA-I government were against the policy of enhanced security cooperation with the Western powers. They regarded it as alienation from the principle of non-alignment and selling off India's sovereign authority to the capitalist West. This opposition was further consolidated when the left parties pulled out their support from the UPA-I over the Civil Nuclear Deal with the US. The hesitance to strategically engage with the Western powers would provoke China, existed even during the UPA-II regime. Also, in this period, the French failed to partner with India in its Indian Ocean initiatives (Saint-Mézard, 2015). Several bureaucrats in the South Block were also pessimistic about these emerging ideas of strategic collaboration. This policy paralysis and coalition blackmailing during the one decade of the UPA regime seriously hampered India's strategic advancements in the region.

However, a change in India's foreign policy approach was observed with the swearing-in of the NDA-I government in 2014. The Modi government imbibed a new sense of activism and rejuvenation in India's foreign policy dynamics. Two factors were responsible for this renewed political approach. First, the absence of coalition burden and Modi's charisma as a tough leader, capable of taking important decisions. Modi was not "burdened by ideological shibboleths" (Mohan \& Baruah, 2018). This renewed pragmatism was further articulated by Modi in his address at the US Congress in 2016. He opined, "India has overcome the hesitations of history."(PM Narendra Modi's Speech in US Congress, 2016). Under his leadership, the scope of political and strategic collaboration with like-minded partners got enhanced. Second, the growing presence of the Chinese in India's maritime backyard was perceived as a potential threat to Indian interests in the region. Initially, the Chinese PLAN was involved in the waters of the Indian Ocean to safeguard its trade and energy routes from piracy. But the docking of a Chinese submarine at the Colombo port in 2014 drew greater significance. Also, by inviting the littoral states of the Indian Ocean to participate in the Maritime Silk Road Initiative, China began to revamp its engagement with these nations. Under the Belt and Road 
initiative (BRI), China invested in the development of the Hambantota port in Sri Lanka. It successfully replaced India in the development of the Male Airport and invested heavily in the infrastructural development of the Maldives. For India, both Sri Lanka and the Maldives are of immense geostrategic importance. There were also other significant developments in the Indian neighborhood - the sale of submarines to Bangladesh and Thailand, growing naval cooperation between Pakistan and China, and a military base in Djibouti. Due to these developments, India did not participate in the Chinese BRI (Ministry of External Affairs, 2017). Also, to balance the growing Chinese presence in the Indian Ocean Region, India initiated the policy of SAGAR (Security And Growth For All) to indicate its willingness to cooperate with partners in the maritime domain. Promoting maritime multilateral and minilateral frameworks will help India to counter an assertive China in the region.

France was also concerned about the growing Chinese assertiveness in the Indo-Pacific region. It viewed China's aggression as a rejection of international sea laws, freedom of navigation, and rule-based order. In the Defence and National Security Strategic Review (2017), France vociferously criticized the growing Chinese threat in the region. It noted "Chinese presence in the region, which started in 2008, is now permanent, and relies both on an operational base in Djibouti and a support facility in Gwadar (Pakistan). This trend reflects China's strategic ambition to develop a long-term naval influence in a maritime area extending from the South China Sea to the whole Indian Ocean. China's activities have been widely seen as the most important element in reshaping the entire region's security dynamic. Littoral states worry about the increase in China's activities: this is true of India (historical stakeholder) as well as of Australia which, like France and the United States, has to cope with security issues both in the Pacific and Indian Ocean." (Defence and National Security Strategic Review, 2017).

The Indo-French convergence of maritime interests is best represented through their cooperation in the Western Indian Ocean. India maintains close political and strategic cooperation with the littoral states of the Western Indian Ocean like Mauritius and Seychelles and East Africa. France has a military presence in the region through its military bases in Djibouti and Abu Dhabi. It also has an EEZ in the Mozambique Channel. In March 2020, India and France conducted a joint coordinated patrol from the Reunion Island, the naval base of France in the Western Indian Ocean. Together, they are exploring opportunities for development projects in the Western Indian Ocean Region (Chaudhury, 2019).

\section{AREAS OF INDIA-FRANCE MARITIME COOPERATION}

The Indo-French strategic partnership signed in 1998 gained significant momentum under Modi and Macron. Since 2017, several key high-level bilateral engagements have taken place which included the visit of Prime Minister Modi to France in 2017 and a reciprocal visit by President Macron in March 2018. At the center of all these dialogues lies the issue of advancing strategic cooperation in the maritime domain. The recently concluded visit (April 2021) by the French foreign minister Jean-Yves Le Drian during this ongoing pandemic reflects the strategic warmth enjoyed by the two partners. The foreign ministers of both nations reiterated their commitment to maritime cooperation in the Indo-Pacific while adhering to the Indo-Pacific Ocean Initiative (IPOI) launched by Modi. In the Indo-France maritime cooperation, there are different areas of future cooperation.

\section{Maritime Domain Awareness}

At the second round of maritime security dialogue (2017), India and France signed the White Shipping Agreement which allowed sharing of information on commercial cargo movement and movement of naval frigates to strengthen maritime domain awareness (Indo-French Dialogue on Maritime Coop \& Signing of White Shipping Agreement, 2017). Based on the strengths of their navies, the two countries can exchange naval intelligence. The root of this intelligence sharing can be traced to the visit of Modi to France in 2015. India's radar for coastal surveillance set up in Sri Lanka, the Maldives, Mauritius, and Seychelles can complement France's surveillance over the critical choke points of the Strait of Hormuz and Bab-el-Mandeb on ocean intelligence sharing. There is greater scope for the two countries to further advance cooperation in information sharing and maritime awareness.

\section{Joint Military Activity}

By utilizing their respective strengthens in the Indian Ocean Region, both countries can collaborate on maximizing their impact through joint efforts. This may include capacity building, joint patrol, cooperation in HADR, disaster aid, and search and rescue operations. France and India are actively collaborating for joint anti- 
piracy operations in the Western Indian Ocean. Also, as a trusted ally of India, France can contribute to India's effort of developing the islands of Andaman and Nicobar by sharing its experience.

\section{Multilateral and Trilateral Cooperation}

Based on their commitment to the idea of multilateralism, India and France can make efforts to expand their close partnership to include countries with similar geostrategic interests in the region. India along with the US, Japan, and Australia are members of the Quadrilateral formation in the Indian Ocean Region. Macron has proposed for ParisDelhi-Canberra Axis at his speech at the Garden Island, Australia. Initiatives at the highest level are already taking place through dialogues and trilateral engagements for the effective realization of the framework for stability in the India-Pacific region. Such trilateral frameworks between India-Japan-Australia and India-IndonesiaAustralia are already taking shape. France, too, maintains trilateral maritime cooperation with New Zealand and Australia in the Pacific Ocean. There is also scope for potential trilateral partnerships with the US, Japan, and the UAE in the region. The platforms of the Indian Ocean Rim Association and the Indian Ocean Naval Symposium can further facilitate multilateral cooperation with the littoral states to upload regional balance and stability.

\section{INDIA'S VISION OF THE INDO-PACIFIC}

The concept of Indo-Pacific gained momentum in India's diplomatic and strategic circle following the speech of Prime Minister Shinzo Abe of Japan to the Indian Parliament on the "Confluence of Two Seas" in 2007. Since then, several strategic and security documents of the Government of India, though few have stressed the idea. An official document of the Indian Navy 'Ensuring Secure Seas: Indian Maritime Security Strategy' published in 2015, mentions the increasing strategic importance of the Indo-Pacific at the international level (Indian Navy, 2015). The National Security Strategy prepared by Lt. General (Retired) D.S. Hooda at the behest of the Indian National Congress, also emphasizes the need to prioritize IndoPacific as a strategic construct. Several Indian defense thinktanks have pointed out the vagueness and contravention in India's Indo-Pacific strategy. To them, India's Act East Policy (earlier, Look East Policy) complements the Indo-Pacific construct, focusing beyond economic and diplomatic collaborations and trying to prioritize security and strategic dimensions with the
Association of Southeast Asian Nations (ASEAN) partners (Rajagopalan, 2020).

The guiding principles of Indian foreign policy that include, non-alignment, respect for territorial integrity, non-interference, and strategic autonomy contribute to India's perception of the Indo-Pacific (Prasad, 2019). Though it is not officially articulated and at times refuted by the South Block, China is viewed as the driving force in India's Indo-Pacific approach. Three factors lead to this argument - first, India views Chinese presence in its neighborhood as a part of Beijing's policy of 'strategic encirclement'; second, China's dominance in the South China Sea poses threat to freedom of navigation, and; the third, increasing presence of Chinese navy in the Indian Ocean (Rajagopalan, 2020). In this regard, according to Rajagopalan, India pursues an 'evasive balancing' strategy i.e., it seeks to expand defense and strategic collaboration with other powers (like Japan, Australia, Vietnam, etc.) in the region while assuring China that it is not directed against it.

In 2015, India and Japan signed the 'India's and Japan's vision 2025' - the 'Special Strategic and Global Partnership Working Together for Peace and Prosperity of the Indo-Pacific Region and the World" (MEA, 2015). This was for the first time that India signed an agreement that mentioned the Indo-Pacific. It was followed by another joint declaration signed between the 'special strategic partners' in 2017 titled 'Toward a Free, Open and Prosperous Indo-Pacific' (Ministry of Foreign Affairs of Japan, 2017). In this declaration, the emphasis was laid on the promotion of 'rule-based order' in the region. It was argued that India's 'Act East' policy can complement Japan's 'Free and Open Indo-Pacific' strategy through collaborations in areas of the maritime domain, engagement with the ASEAN members, developing connectivity, and exchange of defense and strategic experts between the two partner states.

In 2018, Prime Minister Modi's keynote address at the Shangri-la security conference is regarded as the innuendo for India's perception of the Indo-Pacific (MEA, 2018). It provided a comprehensive definition of India's Indo-Pacific understanding i.e., "from the shores of Africa to that of the Americas". In the speech, Modi stressed the benefits of partnership in the region - a shift from the earlier policy of isolationism to active collaborations in foreign policy outreach. He stressed Indian commitment to regional growth and security and strongly argued for greater momentum in partnership with Australia, ASEAN, 
South Korea, etc... For India, Indo-Pacific was neither a strategic congregate nor a strategy to dominate or align against any particular country. It was a 'partnership for development'. The speech acknowledging the emergence of a new world order stressed India's advocacy for multilateralism, free, open, and inclusive Indo-Pacific as well as on rule-based order, customs, and practices. The fundamental components of India's perception of the Indo-Pacific include ASEAN-centrality, providing alternatives to the BRI, promoting freedom of navigation and rule-based order, and enhancement of connectivity through infrastructural development. India seeks to emphasize bilateral trade policy and multilateral security arrangements. By the first quarter of 2020, India has developed a concrete vision of the Indo-Pacific as an arena of opportunities. As the MEA notes, "Through the IndoPacific construct, India envisages a greater role for itself in the wider region." (MEA, 2019). Today the US, Japan, Australia, and France have emerged as natural partners for India's Indo-Pacific collaborations along with the ASEAN and the EU.

Therefore, on one hand, if India is vocal for an inclusive Indo-Pacific, on the other it has adopted policies (e.g., 'evasive balancing') to counter-balance assertive China. As Beijing continues to flex muscle in the IOR, India's primary objective has been to expand its strategic and security partnership with like-minded countries like the US, France, Japan, Australia, etc.... It is involved in bilateral and multilateral naval exercises in the region. The most notable being the annual 'Malabar' exercise that includes India, the US, and Japan (since 2015). In 2020, Australia has also been invited to participate in this exercise. Along with France, India is engaged in anti-piracy operations in the Western Indian Ocean. Apart from this India, is also engaged in humanitarian assistance missions and disaster relief initiatives in the region.

In recent years there has been an exponential rise in Beijing's military presence in the IOR. Initiatives like naval facility in Djibouti, deep seaport development, submarine docking, and oceanographic data mapping of IOR have put to test India's military preparedness in its strategic backyard. Therefore, the Indian navy has formulated Maritime Domain Awareness (MDA) as an effort to trace emerging developments in the region. The MDA seeks to evolve greater 'strategic security awareness' in terms of 'intelligence, surveillance, and reconnaissance in all dimensions' (Baruah, 2020).Concomitantly, India's enhanced cooperation with partner states like the US,
Australia, Japan, and France serves two purposes - First, to address security challenges emanating from terrorism, piracy, cyber warfare, etc., and; Second, to initiate new projects for sustainable and ocean development. India conducts $2+2$ dialogue and/or annual security dialogue with these partner states. It also holds annual maritime security dialogues with the US, Japan, Vietnam, Myanmar, etc... Additionally, there are trilateral and quadrilateral arrangements like the India-Japan-US, the India-AustraliaIndonesia, France-India-Australia, and the India-JapanAustralia-US respectively.

\section{FRENCH VISION OF THE INDO-PACIFIC}

Since the past decade, the concept of Indo-Pacific has gained a reputation as a geopolitical and geostrategic construct in the foreign policy discourse of major world powers like the US, Japan, France, Australia, etc. It has emerged as a new "geopolitical nomenclature" (Hemmings, 2018) in the maritime strategic doctrine, replacing the earlier dominant Asia-Pacific understanding. But among these major powers there remains an ambiguity concerning the definition and perception of this new geopolitical construct(Naha A. , 2020). For instance, Japan incorporated the strategy of "Free and Open IndoPacific" intending to secure global stability and prosperity. The US incorporated the idea to contain the rise of expansionist China while maintaining its sphere of influence in the region by cooperating with like-minded partners like India, Australia, Japan, ASEAN, the UK, etc. As Allan Gyngell argues, the term is an attempt by different regional and extra-regional powers to construct a space in which the national strategies of the state fit (Grare, 2020). For France, from the coasts of East and Southern Africa to the beaches of North, Central, and South America, constitute the idea of Indo-Pacific. In other words, it is "a security continuum which extends from Djibouti to French Polynesia." (Guitton, 2019).

This difference in perception of the Indo-Pacific can be best understood from the increasing Chinese strategic and economic activities in the Indian Ocean Region and beyond. China wants to establish itself as an economic superpower and a military hegemon in the region. The latter is linked to achieving its economic goals by protecting its sources of raw materials and maritime anes of communications. By investing in different Island countries in the region under its Maritime Silk Route Initiative and leasing ports in the name of development, China has utilized its resources in information gathering and strengthening its naval presence 
in the region. However, the real intention of China began to get questioned when in 2017, it opened a military base in Djibouti.

France considers itself as a recognized and rightful player in the Indian Ocean Rim and the Indo-Pacific. The historical root of the French presence in the region can be linked to its colonies and as a counter to the Soviet presence in the region. But in the present scenario, France wants to project itself as a middle power in the IndoPacific with global influence and recognition. According to Britannica, in international relations, middle power is countries that rank below that of a Superpower, but with sufficient capability to shape global events. In this ongoing game of power rivalry between the US and China, France is utilizing its position by partnering with other middle powers in the region to provide an alternative framework consistent with the idea of multipolarity.

The French concept of the Indo-Pacific has matured under
President Macron. The Strategic Review of Defence and National Security (2017)points to the increasing climate of skepticism. It holds that the increasing Chinese assertiveness in the region, as well as the emerging Sino-US confrontation, is a threat to regional security and French interest in the region. France is critical of the increasing Chinese aggression and hegemonic design in the region. In his speech at Garden Island (Australia), Macron stressed the importance of the Indo-Pacific in the French foreign policy doctrine. He pointed out three crucial aspects of France's perception of the Indo-Pacific. First, protecting the French interests from any Chinese aggression; Second, preserving and upholding the US-French relationship irrespective of the unpredictability of the person sitting in the White House; and, Finally, disentangling France from any US-China rivalry. He stressed the need to develop a "New Delhi-Paris-Canberra" (Grare, 2020) partnership for regional peace and stability.

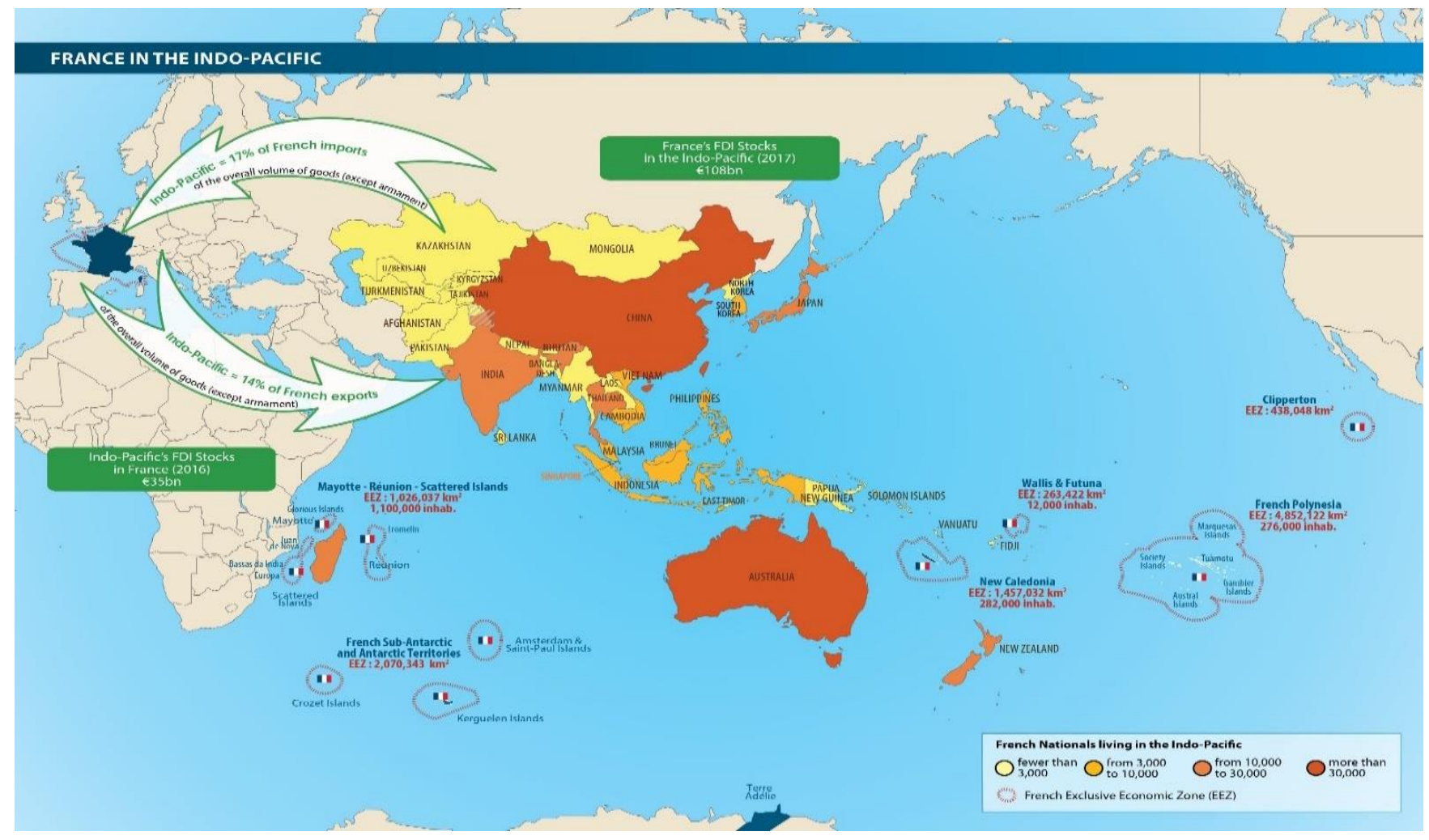

Figure 1. France in the Indo-Pacific.

Source: Ministry of Defense, France.

Macron, through his speeches and addresses, has made it clear that France does not feel any threat to its interests in Indo-Pacific from the Chinese BRI, but is critical of the growing Chinese aggression. While emphasizing the significance of the US-France partnership, he stressed the importance of the US in balancing China in the region and called for broader cooperation among like-minded allies to develop a 
'level-playing ground' in contestation against the Chinese hegemonic design. For Macron, France is a 'balancing power' in the region. The major objectives of the French strategy of Indo-Pacific are to promote freedom of navigation, securing the Sea Lines of Communication or SLOCs, promoting rule-based order, preventing terrorism through sea and piracy, and upholding international sea laws. Apart from these, preserving and protecting the environment and biodiversity is another major component of France's strategic interest in the Indo-Pacific. This is not just for the success of the Paris Agreement but also because degradation of environmental security leads to a fresh epicenter of tensions, redrawing maps, displacing populations, and affecting critical infrastructure (Largemain, 2019). The US has also incorporated the environmental aspect in its Indo-Pacific strategy. The U.S. Indo-Pacific Command (USINDOPACOM) through its Pacific Environmental Security Forum seeks to address environmental security issues by making regional militaries understand environmental obligations and cooperate with NGOs and civilian agencies to find solutions. Washington is aware of the strategic and political repercussions of climate change (Grare, 2020). Central to France's Indo-Pacific strategy is the issue of multilateralism. Through trilateral or multilateral arrangements, France seeks to address the power asymmetry existing in the region. This is where Macron's idea of France as a power balancer becomes crucial as it seeks to provide the smaller countries of the region freedom to take their own decision. For Macron, multilateralism is the means to an end, to preserve the global order. France has engaged with the littoral states of the Indian Ocean Region to strengthen regional security. It maintains a close economic and strategic partnership with countries like UAE, Qatar, Singapore, India, Japan, etc.

The presence of overseas territories and a large number of French Diasporas makes France a regional power in the Indo-Pacific. The overseas territories of New Caledonia, French Polynesia, Wallis and Futuna, Clipperton Island, Reunion Island, Mayotte, Tromelin Island, and the Scattered Islands are central to French understanding of the Indo-Pacific. The territories of Tromelin Island and the Scattered Island are part of the French Southern and Antarctic territories and are of immense economic, strategic, and scientific importance (Modern Diplomacy, 2020). These French overseas territories constitute the "second most important exclusive economic zonein the world." (Grare, 2020). Nearly 90 percent of the French EEZs are located in the Indo-Pacific (Godbole, 2019). This makes France an important player in the region with responsibilities to safeguard the sovereignty of its territories and citizen and to fulfill its global obligations. The protection of the overseas territories makes the Indo-Pacific one of the core aspects of France's National Security Strategy. Moreover, the economic and strategic capability of France makes it a preferred partner for most of the regional powers like India, Japan, etc. These regional powers view France as a major strategic partner in the Indo-Pacific.

The major challenge for France, however, is to retain sovereign control over these overseas territories. French territories like New Caledonia and French Polynesia have already begun to seek independence from France. There is also a looming possibility that Comoros may take over Mayotte with support from Russia and China. Mauritius has also challenged French sovereignty over Tromelin Island. Madagascar is also critical of French control over the Scattered Islands. For France, any loss of territory in the Indo-Pacific will pose a challenge to its role in the region. So, for France integrating the overseas territory with the mainland as well as the regional framework is important. As Ambassador Christian Lechervy states, "the concept of the Indo-Pacific is based on a willingness to connect [these] spaces to their environment, and to ensure sustainable growth, respectful of the environment and of people." (Lechervy, 2019). Apart from these, there are also non-conventional security threats emanating from illegal fishing, the presence of Somali pirates, illegal migration, etc.

In the Northwest Indian Ocean, France maintains two inter-services bases at Abu Dhabi and Djibouti and has a military presence in the Persian Gulf and the Gulf of Aden (Modern Diplomacy, 2020). These bases are strategically important to France for three reasons - first, the Middle East is a conflict-prone region with global security ramifications. The French presence can contribute to installing regional stability; second, the Northwest Indian Ocean has important chokepoints -the Suez Canal, Straits of Hormuz, Bab-el-Mandeb, and the Cape of Good Hope, and important trade and energy import routes like the Persian Gulf and the Mediterranean Sea. The presence of the French military can help to secure these trade routes and SLOCs from any non-conventional threats as well as 
allow it access to the big Asian market. Moreover, the presence of French armed forces in Djibouti helps it to keep a check on the Suez Canal and the Bab-el-Mandeb, while the territories of Reunion Island and Mayotte serve as bases for the French naval patrols in the Mozambique Channel (Harshe \& Gurjar, 2020); and, finally, in consolidating its role in the broader Indian Ocean development framework.

Along with the traditional presence in the Northwest Indian Ocean, France is gradually enhancing its presence in the Eastern Indian Ocean. Pointing to the rise of hegemonic China, France, in 2013 released a White paper mentioning the growing power asymmetry in East Asia. In its effort to counter the Chinese aggressive design, France is collaborating with countries victims of Chinese aggression while creating opportunities to expand its naval presence in the region. In this aspect, France is trying to capitalize on its trusted strategic partnership with India. Also, to do away with its limited operational capacity in the East of the Strait of Malacca, France has signed a strategic partnership with countries like Vietnam, Singapore, and Indonesia.

In terms of France's participation in the regional framework in the Indian Ocean Region, France is one of the architects of the Indian Ocean Commission (1982) and the Indian Ocean Naval Symposium (2008). Its membership of the Indian Ocean Rim Association (IORA) allows it to cooperate with 20 countries of the Indian Ocean Region. In the Pacific, France is one of the founders of the South Pacific Commission (1947) and the Western Pacific Naval Symposium (1998).

To sum up, it may be argued that France's Indo-Pacific strategy is primarily centered on protecting its interests from the threats emanating from Chinese aggression in the region and the emerging Sino-US rivalry. Given the changing world order where the continent of Asia has become the center of a great game of power, France does not seek to lose its influence and importance in the region. For the success of its Indo-Pacific strategy, the role of the French overseas territories becomes crucial. Also, to succeed in this potential confrontation region, France needs to ally with like-minded partners based on the principles of rule of law, protecting human rights, and upholding freedom of navigation.

\section{INDO-FRENCH MARITIME COOPERATION IN THE INDO-PACIFIC}

Indo-France maritime cooperation in the Indo-Pacific is an unexpected consonance. History does not hold much evidence of a deep-rooted partnership and convergence of interests between an emerging nation and a former colonial power. But India and France, with their civilizational idiosyncrasy, stand exceptional. In the post-Cold War global scenario, while India largely maintains an independent and non-aligned foreign policy, France has been critical of the US hegemonic rise and regarded it as a hyperpower. Accepting the realities of the changing global scenario, both these states have embraced the virtues of multipolarity. In present times, the wary over the rise of aggressive China in Asia and to safeguard geo-economics and geostrategic interests in the Indian Ocean Region, it was imperative for both India and France to advance maritime cooperation. There are also underlying geopolitical and geoeconomics similarities of the Indo-Pacific perception between India and France.

In the persisting environment of increasing Chinese aggression in the Indian Ocean Region, President Macron in 2019 complemented the closer strategic cooperation between India and France in the region. This strategic cooperation ranges from sharing the analysis of joint maritime security, deployment of Indian navy maritime patrol vessels in Reunion islands, joint surveillance, etc. In March 2020, India and France conducted a joint coordinated patrol from the Reunion Island, the naval base of France in the Western Indian Ocean. India usually conducts coordinated patrol or CORPAT with its maritime neighbors like Maldives, Mauritius, Bangladesh, Thailand, Seychelles, Myanmar, and Indonesia for the surveillance of the Exclusive Economic Zones. This was the first time that India conducted such a maritime exercise with a foreign power. In 2016, a similar proposal by the U.S. Indo-Pacific Commander Adm. Harry Harris was rejected by India. This change in stance reflects India's resolve to engage with likeminded foreign powers in expanding its sphere of influence in the Indian Ocean Region (Peri, 2020). It also envisages the strategic significance of the region between the East African coastline and the Straits of Malacca (Rajagopalan, 2020). The possibility of such a joint naval exercise with specific objectives was earlier hinted at by the French Navy Chief Admiral Christophe Prazuck. He stated, "looking forward to organizing joint patrols with the Indian Navy in the North-Western Indian Ocean or the Southern Indian Ocean, around the islands that are part of France." (Peri, 2020). 


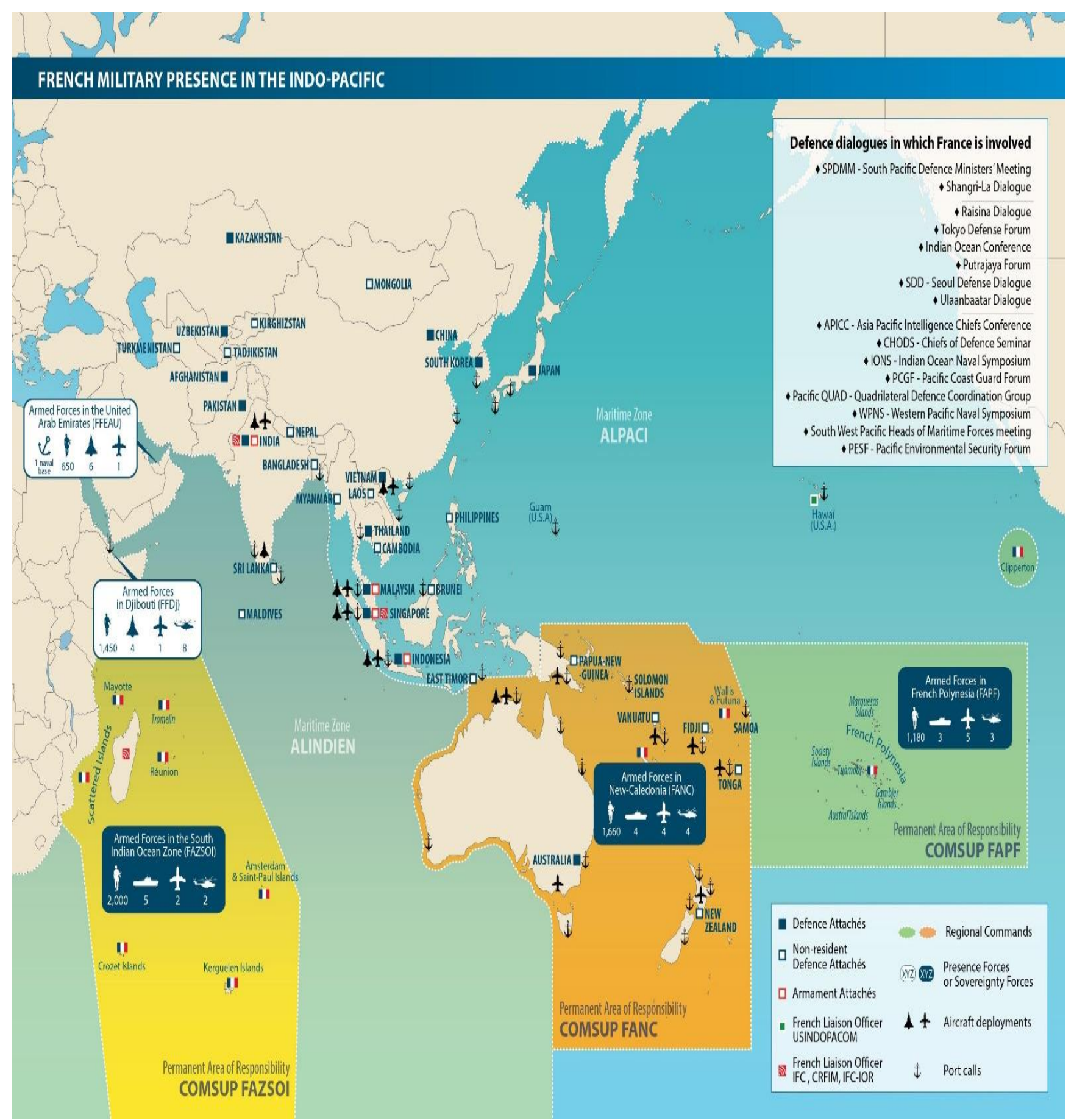

Figure 2. French Military Presence in the Indo-Pacific.

Source: Ministry of Defense, France.

This coordinated exercise reflects the trust and strategic reliability that both countries share. Both India and France complement their demand for freedom of navigation and their role in the broader security framework in the region. France has advocated for India's active role in the South-Western Indian Ocean to counter the menace of piracy. French Armed Forces Minister Florence Parly in her speech at the Shangri-la Dialogue (2019) emphasized the receding values of multilateralism, growing strategic coercion, and depletion of the values of sovereignty, equality, freedom, and non-interference in the internal affairs in the region. 
She stressed the major aspects of France's renewed Indo-Pacific strategy, the notable among them were first, protection of its sovereignty and Exclusive Economic Zones emanating from conventional and nonconventional threats; second, while maintaining the centrality of ASEAN in the region, France will enhance its collaboration with partners like India and Australia to develop a 'regional security architecture' (Au-Yong, 2019); third, questioning the security of the smaller states in the region and to preserve freedom of navigation and sea lanes of trade, she stressed on working with partners and sailing in the South China Sea twice a year to uphold international sea laws. This is in direct retaliation to the growing Chinese monopoly over the South China Sea; and, finally, France's commitment to upholding the principles of multilateralism for regional stability. She argued, "In a peaceful, multilateral but robust way, we hope to accompany the vast rebalancing that is taking place in the region." (Au-Yong, 2019). At the 2018 edition of the Shangri-la dialogue, India maintained an almost similar position. In the keynote address, Prime Minister Modi stressed the benefits of partnership in the region for regional growth and security. The key components of India's Indo-Pacific strategy include - advocacy for multilateralism; free, open, and inclusive Indo-Pacific; rule-based order; the centrality of ASEAN; upholding freedom of navigation, etc. Today, ASEAN, the US, Japan, France, and Australia have emerged as natural partners for India's Indo-Pacific vision. There lies a strategic congruity in the Indo-Pacific strategy of India and France.

The closer strategic partnership between India and France is a sign of reliability that exists. India views France as a trusted partner. It allowed a French Liaison Officer to be stationed at the Indian Navy's Information Fusion Centre (IFC-IOR)(Rajagopalan, 2020). France is the first country to be given such a privilege by India. For India, France is perhaps the second most all-weather strategic partner after Russia. But in recent times the growing synergy between Russia and China has added to the worries of India, due to which India's closeness with France has increased many folds. Describing this enhanced Indo-French synergy, Prime Minister Modi observed, "Today in the $21^{\text {st }}$ century, we talk of INFRA. I would like to say that for me it is IN+FRA, which means the alliance between India and France." (DNA India, 2019). Today, India-France strategic alliance has expanded and deepened significantly. France's support to India at the UNSC in 2019 after the abrogation of Art. 370 signify the depth in the relationship. India's increasing engagement with France in the Indian Ocean is consistent with Modi's policy of "collective action and cooperation will best advance peace and security in our maritime region." (Chaudhuri, 2018). This marks a shift from the earlier policy of isolationism to active collaborations in Indian foreign policy outreach (Naha A. , 2020). Similar to the India-US Logistics Exchange Memorandum of Agreement (LEMOA), India and France in 2018 signed the logistic agreement for equal access to each other's military facilities. This agreement has expanded to include India's naval operations in the Western Indian Ocean. This Indian realistic approach will contribute to strengthening its operational capabilities in the region and open new avenues of strategic cooperation to counter the Chinese hegemonic plan in India's maritime backyard.

\section{'PARIS-DELHI-CANBERRA AXIS' IN THE INDO- PACIFIC}

The increasing Chinese economic and strategic imprint has been a cause of jitters in the Indo-Pacific region (Medcalf, 2018). The Chinese navy or PLAN, through maritime diplomacy, is engaging with various littoral states of the region, making its presence felt by docking submarines and frigate ships in the ports of many South and Southeast Asian nations. China has built a web of naval bases in South Asia, anti-ship ballistic missiles, etc. which if deployed can pose threat to the Indian, US, and other naval forces in the region (ORF Event Report, 2021). Its conduct of military exercises beyond its backyard symbolizes its intention of becoming a major player in the region. Also, the pandemic, as a catalyst has accelerated the geopolitical reorientation of the region. China is regarded as the source of the pandemic. This has resulted in an increasing anti-China sentiment around the globe. Tensions have also emerged between China and countries like India, Australia, the US, Taiwan, etc. In such a situation, the QUAD strategic formation cannot be the only framework for reestablishing regional stability and order. The 'Paris-Delhi-Canberra Axis', as proposed by President Macron at the Garden Island speech in 2017, can emerge as a regional trilateral framework reflecting the "geostrategic reality" in the Indo-Pacific region (Mohan, Medcalf, \& Tertrais, 2018). Along with India and Australia, France would partner to frame a joint Indo-Pacific strategy with definite 
objectives and actions. This strategic axis has moved beyond the purview of track 2 and tracks 1.5 dialogues, like academic debates and discussions, and has emerged as an aspiration to be perceived at the highest level of government.

Among India, France, and Australia, there exists a convergence of democratic ideals, respect for rule-based order, strategic and security interests, opposition to aggression and obtrusion, and emphasis on the sovereign equality of nations. For all the major and regional powers, Indo-Pacific can be the breeding ground of multipolarity. In terms of its geographical spread, it is too big for a hegemon to survive and succeed. But despite this reality, as Macron pointed out there will be "hegemonic temptations" leading to unilateral intimidation, oppression, and encroachment on others' sovereign affairs (Mohan, Medcalf, \& Tertrais, 2018). Due to geo-economics interests, China has already made its military presence felt in South and Southeast Asia and is now exhibiting interests in the South Pacific region. Also, the unpredictability of the US role in the region under President Trump and after has been a cause of apprehension for others. In this respect, Abhijnan Rej observed, "against the backdrop of "recent American unpredictability" U.S. allies in the region are looking to create "a more networked architecture involving a range of often overlapping minilateral arrangements and consultative mechanisms." (Rej, 2020). In such a situation, the 'Paris-Delhi-Canberra Axis' is essential for free, open, and inclusive IndoPacific(Rajagopalan R. P., 2020). Also, what is required is a diversification of the Indo-Pacific security architecture. This diversification involves engagement with various regional and sub-regional powers in the Indo-Pacific. For instance, India, Japan, and Australia while cultivating a close partnership with each other has also developed ties with members of ASEAN like Vietnam, Indonesia, and Singapore.

Central to France's Indo-Pacific strategy is the role of India and Australia. They share the common vision of 'Free and Open Indo-Pacific'. The renaming of the AsiaPacific to the Indo-Pacific by the Trump Administration has established the crucial role of India in the region - a preferred partner for all. Australia is a bridge connecting the two oceans - the Indian and the Pacific. France, on the other, due to the presence of its overseas territories considers itself as a resident player in the Indo-Pacific (Ministry of Armed Forces, 2019). This close partnership among the three has contributed to the emergence of a new "middle power coalition" in the region (Rajagopalan, 2020). The potential of this trilateral formation was in January 2018 at the sidelines of the Raisina Dialogue. Together, they can operate and share information to promote maritime domain awareness, surveillance, combating piracy, counter-terrorism, HADR/SAR, blue economy, preserving marine ecology, logistics support, and increased interoperability (Pandey, 2020). There is also an opportunity for Paris and Canberra to cooperate in the Pacific Ocean. The islands of Reunion and Mayotte (France), Andaman and Nicobar (India), and Cocos and Christmas islands (Australia) can become a chain of naval bases for maritime surveillance in the overall Indian Ocean Region.

Maritime cooperation is a major area of focus in this trilateral axis. Through bilateral naval exercises, India is engaged regularly with Australia and France. In 2020, India and Australia have published Joint Declaration on a Shared Vision for Maritime Cooperation in the IndoPacific recognizing the threats and challenges that emanate from the maritime domain (Ministry of External Affairs, 2020). Also, the Arrangement concerning Mutual Logistics Support (MLSA) was signed between India and Australia in 2020. This will further enhance defense cooperation in the maritime domain by allowing each other access to the strategically located islands of Andaman and Nicobar (India), close to the Strait of Malacca and Cocos Islands (Australia), close to Lombok, Sunda, and Makassar Straits(McHugh, 2011). A similar logistic arrangement exists between India and France signed in 2018 (Reciprocal Logistics Support Agreement). It allows "extend logistical support on reciprocal access to respective facilities for the Indian and French armed forces." (PIB, 2018). During President Macron's visit to India in 2018, India and France signed the Joint Strategic Vision of India-France Cooperation in the Indian Ocean Region, with the desire to partner with other like-minded countries in the region. Also, for the success of India's policy of SAGAR, France and Australia can be potential partners.

The first trilateral dialogue between these three countries was held for the first time in September 2020, amidst the looming crisis of COVID-19. The meeting was attended by the foreign secretaries of these three countries. In the dialogue, while emphasizing their commitments to rule-based order, freedom of 
navigation, promoting multilateralism, cooperation on economic and geostrategic issues, and democratic values; important issues like pandemic management and engagement with existing regional frameworks like ASEAN, IORA, and IOC for regional stability and order was also discussed. The trilateral can evolve as a platform for enhancing the already booming partnership enjoyed bilaterally by India, France, and Australia. France and India are strategic partners since 1998. Also, with Canberra, New Delhi enjoys a Comprehensive Strategic Partnership based on "mutual understanding, trust, common interest and shared values of democracy"(MEA, 2020). The Franco-Australian relationship is also energetic and vigorous. Together, they have published a Joint Statement of Enhanced Strategic Partnership to promote a stable Indo-Pacific (Department of Foreign Affairs and Trade, 2017).

The 'Paris-Delhi-Canberra Axis' is expected to emerge as a determining factor in the regional balance of power. François Delattre, secretary-general of the French Ministry for Europe and Foreign Affairs, observed, "the goal of guaranteeing peace, security and adherence to international law in the Indo-Pacific by drawing on the excellence of bilateral relations between France, India and Australia." (Pandey, 2020). The Indian MEA explained this 'minilateral' as "...convergences in our approach to the Indo-Pacific region and to explore ways to strengthen trilateral cooperation, particularly in the maritime domain." (Rajagopalan R. P., 2020). This trilateral axis provides the framework to enhance mutual synergies through enhanced cooperation in the region and forming a "partnership of equals" (Mohan, Medcalf, \& Tertrais, 2018).

\section{SCOPE FOR INDIA-FRANCE-JAPAN TRILATERAL IN THE INDO-PACIFIC}

In line with the 'Paris-Delhi-Canberra Axis' against growing Chinese aggression and effervescence of the US policies, countries like India, Japan, France, etc. who consider each other as partners in the region, need to get into active cooperation rather than a mere show of interests. A trilateral partnership between India-JapanFrance can become fruitful in countering Chinese influence while addressing mutual concerns. As the vision of Free and Open Indo-Pacific can only be achieved through cooperation based on the principles of "freedom, openness, and inclusiveness" (Katerina Ang, 2021).
In the Indo-Pacific, India, Japan, and France share a common strategic construct and vision. They share the same vision of 'Free and Open' Indo-Pacific. They advocated "rules-based, multilateral regional order and free of hegemony Indo-Pacific region where countries with similar goals can engage in formulating cooperative policies." (ORF Event Report, 2021). However, the possible trilateral coordination between the three partners is still vague. Within maritime security, the crucial aspect is to express inward and outward coordination in a rational framework where a nation can search for areas with maximum impact (Nayak, 2021). Maritime security is about identifying areas where the entire region can be mobilized as countries are committed to multilateralism. It is more than just a political issue (Maini, 2020). This can be realized by understanding the benefits of collaboration in the maritime realm to preserve a safe and secure maritime milieu and a stable Indo-Pacific. In this respect the role of the ' $3 \mathrm{Cs}$ ' - Confluence, Crisis, and the Convenient is important.

Until the middle of the second decade of the $21^{\text {st }}$ century, the coalescence of the Indian Ocean and the Pacific Ocean had little or no strategic reality. But after 2017, there has been an increasing sense of Confluence of interests - both in terms of thought and mental alignment. For instance, the convergence of security interests between India, France, and Japan in the IndoPacific is due to their mutual strategic compatibility. Though there are sticking points emanating from nonconventional threats like illegal fishing, climate change criminal trafficking, loss of marine ecosystem, etc. to which solution needs to be found. This can be achieved by sharing information in the maritime sphere (PIB, 2018). In this regard, the role of IORA is worth mentioning. India is a founding member of the IORA; France has recently been inducted into the arrangement and Japan enjoys an observer status. This multilateral framework can be utilized by these 3 possible partners to extract the effective result concerning maritime cooperation. A similar partnership on the capacitybuilding program can be realized in Africa.

As a member of the G20, India, France, and Japan can contribute positively to sustainable growth through digital technology apart from maritime security. This can have positive implications for the smaller nations of the region. France and Japan can also invest in these smaller states to develop digital infrastructure and technology to 
fight against cyber threats. In today's world, cybercrime and cyber-attacks have emerged as a bigger transborder security threat. Also, in this pandemic-affected world, people have become more associated with cyber life and are becoming victims of cybersurveillance and tracking. So, there is an opportunity for India, Japan, and France to collaborate among themselves for influencing the future of the digital revolution.

The trilateral partnership can be further realized if Japan and India support France's candidature to theHeads of Asian Coast Guard Agencies Meeting (HACGAM). Japan can also extend support to France's induction into the multilateral security framework in East Asia like the ASEAN Defence Ministers' Meeting Plus (Nayak, 2021). Both Japan and France in recent times have expressed their willingness to establish a long-term strategic partnership by collaborating in areas like space, marine surveillance, cyberspace, etc. (Pajon, 2018). India and Japan can also include France as a participant in the existing coast guard cooperation framework. Fishing is an area of mutual interest. It can emerge as a strategic realm with overlapping maritime and economic considerations. The Chinese contribution to regional imbalance is not only due to the presence of its large navy but also due to its use of unreported and unregulated fishing practices as a means of pursuing geostrategic interests. It uses fishing vessels and the coast guard as a proxy for the PLAN to implement its revisionist agenda. (Forum, 2020). Along with this, there is also a future possibility of the QUAD+France coordination in the Indo-Pacific. Such a possibility has already been on display in April 2021, when the QUAD countries (India, the US, Japan, and Australia) participated in the French naval exercise 'La Perouse' in the Bay of Bengal (Pandit, 2021).

Since the Indo-Pacific region is prone to natural calamities, India, Japan, and France can also collaborate to undertake joint Humanitarian Assistance and Disaster Relief (HADR) operations. The Acquisition and Cross Servicing Agreement (ACSA) was signed in 2018, allowing sharing of defense supplies and services. It is a positive step towards HADR and peacekeeping in the region and will open avenues for future joint initiatives among the three partners. In this respect, India, being established regionally as a 'first responder' to disaster relief, can lead the trilateral cooperation. Such coordinated initiatives will maximize their contribution to the region. The platform of IORA can be further utilized to undertake new development initiatives in the region.

This Trilateral framework once actualized can stimulate broader Asian informality and strengthen cooperation in the region (Nayak, 2021). Keeping aside the bilateral hindrances, the partnership can succeed based on consultation, connectivity, capacity building, and sustainable infrastructure development (Panda, 2020).

\section{CONCLUSION \& RECOMMENDATIONS}

The preceding year has put to light the growing incongruity between the demands for promoting multilateralism compared to the weaknesses of the existing multilateral frameworks. These shortcomings were further accentuated by the pandemic COVID-19. The multilateral institutions became the platform for global contestation rather than cooperation and demanded urgent reforms for greater transparency. Today, the threat to the world system is not just from terrorism and inter-state conflicts but increasing public health disorder, climate change, and cyber warfare. Taking into account the recent coordinated success in the formation of the International Solar Alliance, the Franco-Indian partnership stands as a role model in overcoming these emerging global crises. Their willingness to cooperate with the developing and peripheral countries in tackling the menace of COVID-19 under the frameworks of ACT and COVAX provides them the opportunity to provide leadership in issue-based multilateral institutions.

The region of the Indo-Pacific has emerged as a hotbed of geopolitical contestation. A report by the US Energy Information Administration argues that nearly 39 million barrels of crude oil are transported through the important choke points of the Strait of Hormuz and the Strait of Malacca in the Indian Ocean (World Oil Transit Chokepoints Analysis Brief, 2019). For India, the Indian Ocean is its strategic backyard and the increasing Chinese presence through the BRI is a challenge to its sovereign authority in the region. In the subcontinent, India fears that countries like Sri Lanka, the Maldives, Bangladesh, etc. are at risk of being debt-trapped by China. For instance, the Maldives is under significant Chinese debt and is seeking Indian help for a bailout. This rise of aggressive China is also perceived as a threat by France. Paris is also critical of the Chinese intentions behind the BRI. As Macron observed that the modernday "Silk Road" cannot be "one way". He observed, "After 
all, the ancient Silk Roads were never only Chinese. By definition, these roads can only be shared. If they are roads, they cannot be one-way."(Rose, 2018). In this context, France and India partnership can be a way forward in addressing their mutual concern vis-à-vis China. Together, they share the vision of safeguarding human rights and international values (Behal, 2018). Increased interoperability between the Indian and French navies has made India France's primary partner in the region. Their willingness to jointly develop a maritime surveillance system can help India establish itself as a net security provider in the region while allowing France to indirectly influence the regional security architecture. Also, France's support to India immediately after the Galwan Valley incident and its ontime delivery of Rafale fighter jets reflects the centrality of India in French foreign policy. Cooperation with France can shape the dynamics of India's maritime security role in the Indo-Pacific.

For India and France, there is an overlapping interest in the Indo-Pacific. In the Indo-Pacific, the Indo-French collaboration must continue in areas like maritime domain awareness, cybercrime, HADR, anti-piracy operations, blue economy, etc. Apart from the evolving QUAD framework where India is a member, France and India must try to explore opportunities to build trilateral partnerships with like-minded countries for promoting regional stability and order. While the Paris-DelhiCanberra Axis is already taking shape, the emerging possibility of a Paris-Delhi-Tokyo Axis should not be ruled out. Britain can also become a viable partner for India and France in the region. Recently Foreign Secretary of the UK D. Raab on his visit regarded both India and the UK as "global force for good"(Ministry of External Affairs, 2021). As three successful democracies, their cooperation in the Indo-Pacific can promote new synergy.Along with Japan, together they can be influential in reducing Chinese clout in Africa.This will provide a viable alternative to the African nations and reduce the cost of development projects.These minilaterals are task-oriented informal settings, providing greater opportunity for collaboration without been seen as an alliance against any third country. The Indo-Pacific strategy of India and France should not be just limited to curtailing the rise of China but aim towards greater regional integration and development while upholding international laws to realize 'Free and Open Indo-Pacific'. Incremental, yet sustained, expansion of maritime cooperation could help each side overcome their traditional inhibitions. Therefore, the Indo-Pacific makes up the missing regional anchor to boost the strategic partnership between India and France. A more intensive maritime collaboration could help both countries and make the region less susceptible to emerging shifts and rivalries in U.S.-China relations. More importantly, it could imbibe fresh wind within the sails of India's engagement with Western maritime democracies. This may benefit India by overcoming the legacy of military isolationism and lend credibility to its claims as a "net security provider" within the IndoPacific and to its aspiration of being a "global power."

\section{REFERENCES}

Au-Yong, R. (2019, June 2). Shangri-La Dialogue: France reaffirms commitment to Indo-Pacific. The Straits Times. Retrieved April 8, 2021, from https://www.straitstimes.com/singapore/francereaffirms-commitment-to-indo-pacific

Baruah, D. (2020). India in the Indo-Pacific: New Delhi's Theater of Opportunity. Carnegie India.

Behal, A. (2018). India and France: Towards a new maritimepartnership. Observer Research Foundation.

Chaudhuri, R. R. (2018). Strengthening maritime cooperation and security in the Indian Ocean. The International Institute for Strategic Studies. Retrieved April 8, 2021, from https://www.iiss.org/blogs/analysis/2018/09/m aritime-cooperation-indian-ocean

Chaudhury, D. R. (2019, October 24). India, France explore 3rd country projects in Western Indian Ocean region. The Economic Times. Retrieved April 10, 2021, from https://economictimes.indiatimes.com/news/def ence/india-france-explore-3rd-country-projectsin-western-indian-oceanregion/articleshow/71743985.cms?from $=\mathrm{mdr}$

(2017). Defence and National Security Strategic Review. Paris: Government of the French Republic.

Department of Foreign Affairs and Trade. (2017). Joint statement of enhanced strategic partnership between Australia and France. Canberra: Government of Australia. Retrieved April 10, 2021, from https://www.dfat.gov.au/geo/france/Pages/jointstatement-of-enhanced-strategic-partnership- 
between-australia-and-france

DNA India. (2019). INFRA is IN+ FRA, stands for IndiaFrance alliance: PM Modi at UNESCO HQ. DNA. Retrieved April 8, 2021, from https://www.dnaindia.com/world/photo-gallerypm-modi-in-france-macron-pushes-for-india-spermanent-seat-in-un-security-council-2784133

Forum. (2020). Nations work to counter increased illegal fishing by Chinese fleets. Retrieved April 9, 2021, from

https://ipdefenseforum.com/2020/12/nationswork-to-counter-increased-illegal-fishing-bychinese-

fleets/\#: :text=Nations\%20work\%20to\%20coun ter\%20increased\%20illegal\%20fishing\%20by $\% 2$ 0Chinese $\% 20$ fleets,-

IPDForum\%20December\%2028\&text=Authorities $\% 20$ in $\% 20$ Palau $\% 2$

(n.d.). France and Security in the Asia-Pacific. Government of the French Republic.

French Embassy. (2005). Dr. Manmohan Sings' visit to France, September 15, 2005. French Embassy in New Delhi. Retrieved April 5, 2021, from https://in.ambafrance.org/Dr-Manmohan-Singsvisit-to-France

Gireesh, T. (2020). Indo-French Relations: The New Strategic Contours. Center For Land Warfare Studies (CLAWS). Retrieved April 13, 2021, from https://www.claws.in/indo-french-relations-thenew-strategic-contours/

Godbole, A. (2019). India and France converge in IndoPacific. Mumbai: Gateway House. Retrieved April 9, 2021, from https://www.gatewayhouse.in/india-france-indopacific/

Government of the French Republic. (2009). Blue Book: A National Strategy for the Sea and Oceans. Paris. Retrieved April 11, 2021, from https://ciencias.ulisboa.pt/sites/default/files/fcul /investigacao/French\%20national\%20strategy\% 20for\%20the $\% 20$ sea $\% 20$ and $\% 20$ oceans $\% 20 \% 2$ 8Blue\%20Book\%2C\%2008-12-2009\%29.pdf.

Government of the French Republic. (2013). French White Paper: Defence and. Paris. Retrieved April 10, 2021, from https://otan.delegfrance.org/White-Paper-onDefence-and-National-Security.

Grare, F. (2020). France, the Other Indo-Pacific Power.
Carnegie Endowment for International Peace.

Guitton, A. (2019). What strategy for France in the IndoPacific? Diplomatie, 53, 24-28.

Harshe, R., \& Gurjar, S. (2020). Indian Ocean and Major Powers. In A. B. Chaudhury, \& V. Kumar (Eds.), Understanding Transition in South Asia: Economy,Politics and Society (p. 249). India: Academic Foundation Press.

Hemmings, J. (2018). Global Britain in the Indo-Pacific. London: Asia Studies Centre, Henry Jackson Society.

(n.d.). Indian Defence Industry: Domestic Production and Imports for the Future Balance. Retrieved April 5, 2021, from http://www.nti.org/_e_research/official_docs/cia/ 111501CIA.pdf

Indian Navy. (2015). Ensuring Secure Seas: Indian Maritime Security Strategy. Naval Strategic Publication 1.2. Retrieved April 11, 2021, from https://www.indiannavy.nic.in/sites/default/files /Indian_Maritime_Security_Strategy_Document_2 5Jan16.pdf

(2017). Indo-French Dialogue on Maritime Coop \& Signing of White Shipping Agreement. Government of the French Republic. Retrieved April 11, 2021, from https://in.ambafrance.org/Indo-French-Dialogueon-Maritime-Coop-signing-of-White-ShippingAgreement.

Katerina Ang. (2021). Europe pivots to Indo-Pacific with 'multipolar' ambitions. Nikkei Asia. Retrieved April 9, 2021, from https://asia.nikkei.com/Spotlight/AsiaInsight/Europe-pivots-to-Indo-Pacific-withmultipolar-

ambitions\#: :text=The\%20head\%20of\%20Asia\% 2DPacific,strategy $\% 20$ for $\% 20$ dealing $\% 20$ with $\% 2$ 0China.

Kuo, M. A. (2018, January 25). The Origin of Indo-Pacific as Geopolitical Construct. The Diplomat.

Largemain, M. (2019). Environmental anticipation in the Indo-Pacific: a challenge for French national security. Diplomatie, 53, 29-30.

Lechervy, C. (2019). France and the concept of the IndoPacific. Politique Etrangère, 26. Retrieved April 7, 2021, from https://www.cairn.info/revuepolitique-etrangere-2019-3-page-23.htm

Maini, T. S. (2020). Multilateralism is alive and well in 
the Indo-Pacific. Notes on Liberty. Retrieved April 9, 2021, from https://notesonliberty.com/2020/05/17/multilat eralism-is-alive-and-well-in-the-indo-pacific/

(n.d.). Maritime Safety and Security. Priorities and Focus Area, Indian Ocean Rim Association.

McHugh, L. (2011). History repeating: Australian military power in the Cocos Islands. The Conversation.

MEA. (2005). Annual Report (2004-05) Ministry of External Affairs. New Delhi: Ministry of External Affairs, Government of India.

MEA. (2009). Annual Report (2008-09) Ministry of External Affairs. New Delhi: Ministry of External Affairs, Government of India.

MEA. (2015). India-France Joint Statement during the visit of Prime Minister to France. New Delhi: Ministry of External Affairs, Government of India.

MEA. (2015). Joint Statement on India and Japan Vision 2025: Special Strategic and Global Partnership Working Together for Peace and Prosperity of the Indo-Pacific Region and the World. New Delhi: Ministry of External Affairs, Government of India. Retrieved April 11, 2021, from https://www.mea.gov.in/bilateral-

documents.htm?dtl/26176/Joint_Statement_on_In dia_and_Japan_Vision_2025_Special_Strategic_and_ Global_Partnership_Working_Together_for_Peace_ and_Prosperity_of_theIndoPacific_R

MEA. (2018). Prime Minister's Keynote Address at Shangri La Dialogue. Ministry of External Affairs, Government of India. Retrieved April 11, 2021, from https://mea.gov.in/SpeechesStatements.htm?dtl/29943/Prime_Ministers_Keyn ote_Address_at_Shangri_La_Dialogue

MEA. (2019). Annual Report 2018-19. New Delhi: Ministry of External Affairs, Government of India.

MEA. (2020). Joint Statement on a Comprehensive Strategic Partnership between Republic of India and Australia. New Delhi: Ministry of External Affairs, Government of India. Retrieved April 10, 2021, from https://mea.gov.in/bilateraldocuments.htm?dtl/32729/Joint_Statement_on_a_ Comprehensive_Strategic_Partnership_between_R epublic_of_India_and_Australia

Medcalf, R. (2018). China and the Indo-Pacific: Multipolarity, Solidarity and Strategic Patience. Paper presented at the Grands enjeux stratégiques contemporains - Chaire en Sorbonne Université Paris 1 Panthéon-Sorbonne. Retrieved from rory_medcalf_sorbonne_indo-

pacific_march_2018.pdf

Ministry of Armed Forces. (2019). France and Security in the Indo-Pacific. France.

Ministry of Defense. (2016). France and Security in the Asia-Pacific. Paris: Government of the French Republic. Retrieved April 11, 2021, from 201606PlaquetteAsiePacifique2014ENBD.pdf.

Ministry of External Affairs. ( 2020). Joint Declaration on a Shared Vision for Maritime Cooperation in the Indo-Pacific Between the Republic of India and the Government of Australia. New Delhi: Ministry of External Affairs, Government of India.

Ministry of External Affairs. (2017). Official Spokesperson's Response to a Query on Participation of India in OBOR/BRI Forum. New Delhi: Ministry of External Affairs, Government of India. Retrieved April 10, 2021, from http://www.mea.gov.in/media-

briefings.htm?dtl/28463/Official_Spokespersons_ response_to_a_query_on_participation_of_India_in_ OBORBRI_Forum.

Ministry of External Affairs. (2021). Joint Statement on India-UK Virtual Summit (Roadmap 2030 for a Comprehensive Strategic Partnership). New Delhi: Ministry of External Affairs, Government of India. Retrieved April 10, 2021, from https://mea.gov.in/bilateral-

documents.htm?dtl/33837/Joint+Statement+on+I ndiaUK+Virtual+Summit+Roadmap+2030+for+a+ Comprehensive+Strategic+Partnership

Ministry of Foreign Affairs of Japan. (2017). Japan-India Joint Statement. Toward a Free, Open and Prosperous Indo-Pacific. Retrieved April 11, 2021, from

https://www.mofa.go.jp/files/000289999.pdf

Modern Diplomacy. (2020). India and France Cooperation in the Indo-Pacific: Necessity of the Hour. IFCCI. Retrieved April 7, 2021, from https://www.ifcci.org.in/news/n/news/indiaand-france-cooperation-in-the-indo-pacificnecessity-of-the-hour.html

Mohan, C. R. (2012). From Isolation to Partnership: The Evolution of India's Military Diplomacy. Institute of South Asian Studies Working(Paper no. 144).

Mohan, C. R., \& Baruah, D. (2018). Deepening the India- 
France Maritime Partnership. India: Carnegie Endowment for International Peace.

Mohan, C. R., Medcalf, R., \& Tertrais, B. (2018, May 8). New Indo-Pacific axis. The Indian Express. Retrieved April 10, 2021, from https://indianexpress.com/article/opinion/colum ns/emmanuel-macron-india-france-relationsparis-delhi-canberra-axis-malcolm-turnbullnarendra-modi-5167221/

Naha, A. (2020). India and the Indo-Pacific: An Appraisal. In N. H. Laskar (Ed.), International Relations: Emerging Issues (p. 69). New Delhi: Authors Press.

(2015). National Strategy for the Security of Maritime Areas. Paris: Government of the French Republic. Retrieved April 10, 2021, from http://www.gouvernement.fr/sites/default/files/ contenu/piecejointe/2016/01/strategie_nationale_de_surete_de s_espaces_maritimes_en_national_strategy_for_the _security_of_maritime_areas.pdf

Nayak, S. (2021). Maritime Opportunities Await the India-Japan-France Trilateral. Kolkata: Observer Research Foundation.

ORF Event Report. (2021). The India-Japan-France trilateral cooperation to tackle the rising Chinese hegemony. New Delhi: Observer Research Foundation.

Pajon, C. (2018, November). France and Japan: The IndoPacific as a Springboard for a Strategic Partnership. Elcano Policy Paper. Retrieved April 9, 2021, from https://www.ifri.org/en/publications/publication s-ifri/articles-ifri/france-and-japan-indo-pacificspringboard-strategic

Panda, J. (2020). Australia-India-Japan Trilateral must overcome 'connect contradictions'. New Delhi: Manohar Parrikar Institute for Defence Studies and Analyses. Retrieved April 9, 2021, from https://idsa.in/idsanews/panda-commentary-onaustralia-india-japan-trilateral

Pandey, P. (2020). India-France-Australia: Emerging Trilateral in the Indo-Pacific. New Delhi: Indian Council of World Affairs.

Pandit, R. (2021, April 5). Eye on China, Quad-plusFrance exercise kicks off in Bay of Bengal. The Times of India. Retrieved April 10, 2021, from https://timesofindia.indiatimes.com/india/eyeon-china-quad-plus-france-exercise-kicks-off-in- bay-of-bengal/articleshow/81917310.cms

Pant, H. V., \& Krishna, M. S. (2020). Lessons from 2020 - Next steps for the France-India partnership. New Delhi: Observer Research Foundation.

Peri, D. (2020, March 21). In a first, India, France conduct joint patrols from Reunion Island. The Hindu. Retrieved April 8, 2021, from https://www.thehindu.com/news/international/i n-a-first-india-france-conduct-joint-patrols-fromreunion-island/article31129323.ece

PIB. (2018). India-France Joint Statement during State visit of President of France to India. New Delhi.

PIB. (2018). India-Japan Development Cooperation in the Indo-Pacific, including Africa. New Delhi: Prime Minister's Office, Government of India. Retrieved April 9, 2021, from https://www.mea.gov.in/bilateraldocuments.htm?dtl/30544/IndiaJapan_Fact_Sheet $\mathrm{s}$

PM Narendra Modi's Speech in US Congress. (2016, June 10). Indian Express. Retrieved April 10, 2021, from

http://indianexpress.com/article/india/indianews-india/prime-minister-narendra-modi-uscongress

Prasad, N. (2019). India's Foray into the Indo-Pacific: Embracing Ambiguity through Strategic Autonomy. Retrieved April 11, 2021, from https://www.ide.go.jp/library/Japanese/Publish/ Download/Report/2018/pdf/2018_2_40_011_ch0 7.pdf

PTI. (2015, April 11). Modi, Hollande agree to 17 terms including stalled nuclear project. The Indian Express. Retrieved April 5, 2021, from https://indianexpress.com/article/india/indiafrance-sign-17-agreements-during-pm-modisvisit/

Rajagopalan, R. (2020). Evasive Balancing: India's Unviable Indo-Pacific Strategy. International Affairs, 96(1), 75-93.

Rajagopalan, R. P. (2020). Rise of the minilaterals: Examining the India-France-Australia trilateral. New Delhi: Observer Research Foundation.

Rajagopalan, R. P. (2020, March 26). What's Behind the Rising India-France Maritime Activity in the IndoPacific? The Diplomat. Retrieved April 8, 2021, from https://thediplomat.com/2020/03/whatsbehind-the-rising-india-france-maritime-activity- 
in-the-indo-pacific/

Rault, Y.-M. (2013). France \& India: Decoding the Strategic Partnership. New Delhi: Institute of Peace and Conflict Studies. Retrieved April 13, 2021, from https://www.files.ethz.ch/isn/175040/SR147Yves-IndiaFrance.pdf

Rej, A. (2020, August 28). An India-Australia-France Trilateral Dialogue Is Overdue. The Diplomat. Retrieved April 10, 2021, from https://thediplomat.com/2020/08/an-indiaaustralia-france-trilateral-dialogue-is-overdue/

Roger, C. (2007). Indo-French Defence Cooperation Friends in Need or Friends Indeed? Institute of Peace and Conflict Studies. Retrieved April 05, 2021, from https://www.files.ethz.ch/isn/55131/IPCSResearchPaper7-Constance.pdf

Rogers, J. (2013). European (British and French) Geostrategy in the Indo-Pacific. Journal of the Indian Ocean Region, 9(1), 69-89.

Rose, M. (2018, January 8). China's new 'Silk Road' cannot be one-way, France's Macron says. Reuters. Retrieved April 12, 2021, from https://www.reuters.com/article/us-chinafrance/chinas-new-silk-road-cannot-be-one-wayfrances-macron-says-idUSKBN1EX0FU

Saint-Mézard, I. (2015). The French Strategy in the
Indian Ocean and the Potential for Indo-French Cooperation. Singapore: Rajaratnam School of International Studies. Retrieved April 10, 2021, from https://www.rsis.edu.sg/wpcontent/uploads/2015/03/PR150312_FrenchStrategy.pdf.

Shukla, S. (2019, August 26). Alongside Modi, G7 members have 8 more 'special invitees' for company in Biarritz. The Print. Retrieved April 13, 2021, from https://theprint.in/world/who-arethis-years-g7-special-invitees-and-why-they-arespecial/282141/

Singh, S. (2019). India's Strategic Partnership with France Under Modi Regime. In S. Singh (Ed.), India's Foreign Policy: Reshaping in the Contemporary World (pp. 277-278). New Delhi: Meena Book Publications.

Sood, R. (2020). Why France is a reliable strategic partner for India. New Delhi: Observer Research Foundation.

(2008). The French White Paper on Defence and National Security. New York: ODILE JACOB PUBLISHERS.

(2019). World Oil Transit Chokepoints Analysis Brief. US Energy Information Administration. Retrieved April 11, 2021, from https://www.eia.gov/international/analysis/spec ial-topics/World_Oil_Transit_Chokepoints

Publisher's note: EScience Press remains neutral with regard to jurisdictional claims in published maps and institutional affiliations.

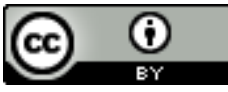

Open Access This article is licensed under a Creative Commons Attribution 4.0 International License, which permits use, sharing, adaptation, distribution and reproduction in any medium or format, as long as you give appropriate credit to the original author(s) and the source, provide a link to the Creative Commons license and indicate if changes were made. The images or other third-party material in this article are included in the article's Creative Commons license, unless indicated otherwise in a credit line to the material. If material is not included in the article's Creative Commons license and your intended use is not permitted by statutory regulation or exceeds the permitted use, you will need to obtain permission directly from the copyright holder. To view a copy of this license, visit http://creativecommons.org/licenses/by/4.0/.

(C) The Author(s) 2021. 